\title{
LONGEVITY OF KABULI CHANA INFLUENCED BY DAMAGE OF COLLOSOBRUCHUS ANALIS.
}

\author{
Vipin Babhulkar1, Ashish Lambat², Prachi Lambat ${ }^{3}$, Rajesh Gadewar ${ }^{4}$, Atul \\ Banginwar 5 \\ ${ }^{1}$ Assistant Professor, College of Agriculture (Dr. PDKV's) Gadchiroli. \\ 2 Sevadal Mahila Mahavidyalaya and Research Academy, Nagpur (MS) \\ 3 D.R.B. Sindhu Mahavidyalaya, Nagpur \\ ${ }^{4}$ Sevadal Mahila Mahavidyalaya and Research Academy, Nagpur (MS) \\ ${ }^{5}$ Assistant Professor, College of Agriculture (Dr. PDKV's) Nagpur.
}

\begin{abstract}
:
Kabuli Chana is an important sources of protein. The seed infestation by pulse beetle during storage is a major problem. This paper gives a brief account of certain Physical, Physiological, Biochemical and Mycological changes in qualities of Kabuli Chana seeds due to infestation of pulse beetle during storage. In the present study, it was found that the percentage of moisture content, total ash, crude fiber, crude protein significantly increased and crude fat total carbohydrate, total sugar pulse beetle reducing sugar and non-reducing sugar significantly decreased in pulse beetle infested seeds of Kabuli Chana during storage. Increase in protein content is attributed to insect metabolites like uric acid, which is nitrogenous is nature. The incidence percentage of fungi such as species of Alternaria, Aspergillus, Curvularia, Fusarium Penicilium and Rhizopus were predominant over all other fungi on infested Kabuli Chana seeds and it is increased with increase in pulse beetle infestation during storage. The physical and physiological qualities of Kabuli Chana seeds i.e. 100-seed weight, germination, seedling vigour and field emergence percentage decreased with increase in infestation of pulse beetle during storage.
\end{abstract}

Key words: - Kabuli Chana, Bruchid, infestation, seed quality and storage.

\section{INTRODUCTION:}

Pulses are the most important source of protein in Indian diet. Storage of pulse seeds is a major problem and it is estimated that about $10 \%$ of stored pulse seeds are lost due to biological factors of which insects and rodents alone account of $5 \%$. In severe cases the infestation was observed to be about $90 \%$. Pulse beetles of various species belong to the family Bruchidae are important insect pest attacking variety of pulses in store. Adult female stick their eggs on the pulse seeds and the emerging grubs and bore into the seeds. The grubs remain inside the seed and appearance of a capped exit hole on the seed indicates the pupil stage. After a few days the adult emerges from the seed. About one month is required to complete one generation.

The stored grain insect's pest's infestation also encourages fungus growth by increasing the moisture content of the seeds which decreased the quality and viability of the seeds. Christensen and
Kaufmann (1969) reported that the fungal pathogen associated with stored seed are chiefly responsible for seed deterioration and reduction in germination potential. Apart from this the seedling vigour is also adversely affected. Among the storage fungi species, many were well known toxin producers. The present work was carried out to investigate the post-harvest losses in qualities of Kabuli Chana seeds due to pulse beetle infestation.

\section{MATERIAL AND METHODS :-}

Kabuli Chana freshly threshed seeds by multi crop thresher which were then cleaned and sieved with $10 / 64$ inch $(3.96 \mathrm{~mm})$ diameter sieve to remove small fraction of seeds or insects produced in 2017 2018. The seeds were dried upto the safe moisture level $(10 \pm 1 \%$ wb) The experiment conducted in glass bottle of two litre capacity. The glass bottle was then filled with 1,000 grams of Kabuli Chana. There were four replications. Ten pairs of 2-3 days old pulse beetle (Callosobruchus analis) were 
released in glass bottles covered with muslin cloth. The set of experiment was kept in well ventilated wire mesh almirah in mesonary building having cemented walls, roof and floor under ambient temperature $\left(10.0\right.$ to $\left.48^{\circ} \mathrm{C}\right)$ and relative humidity (25 to 88\%) from January 2017 to June 2017. For determination of physical, physiological, biochemical and mycological changes in stored seeds of Kabuli Chana were observed at interval of 3 months. The initial observations also taken at the start of experiment. The physical qualities of Kabuli Chana seeds i.e. seed infestation percentage, moisture content and 100 seeds weight were studied. 100 seed weight was tested in quadruplicated with 100 seeds in each replication. The infested seeds we counted and total damaged seeds were reported in percentage. Moisture percentage was estimated according to International rule for seed testing (Anon. 1985). The physiological qualities of Kabuli Chana seeds i.e. seed germination, seeding vigour and field emergence were studied. The germination percentage was evaluated on the value for percent normal seedlings (Anon. 1985). The seedling vigour index was worked our following the method of Abdul-Baki and Anderson (1973. For field emergence test, sowing of Kabuli Chana seeds was done in randomized block design with four replications with inter and intra-row spacing of 1 feet and 6 inches respectively. Observations for field emergence were recorded daily and finally the established seedlings were counted after one month of sowing.

To assess the biochemical qualities of the seeds of Kabuli Chana i.e. protein, fat, total ash, crudefibre, reducing and non-reducing sugars according to the standard procedures of A.A.C.C. (Anon., 1962). Values for carbohydrate and total sugar were calculated (Joslyn, 1970) The fungal flora of the seeds were detected by the standard moist blotter and agar medium techniques as prescribed by I.S.T.A. (Anon., 1976) the different types of fungal growth on the seeds were expressed in percentage. The experimental data was statistically scrutinized as per Panse and Sukhatme, 1967. (The experiment needed more treatment to compare, should divide ages of pulse beetles or make some method to protect seeds).

\section{RESULTS AND DISCUSSION}

It was observed from the Table 1 that the moisture content of the seeds increased with increasing the storage periods i.e. 3 months $(11.1 \%)$ and 6 months (11.7\%). A significant increase in moisture content was observed this might be due to the activities of pulse beetles on seeds during storage. Similar observation also reported by Shrivastava et al. (1989). Gadewar et al. (2011) Seed damage is increased with increasing the storage periods of 3 months $(25.10 \%)$ and 6 months $(59.28 \%)$ respectively. Charjan et al. (2006) and Gadewar et al. (2011) reported that the infestation of pulse beetles increased with increasing the storage periods. The 100-seed weight of seed decreases with increasing the storage periods. Similar observation also reported by Charjan (1995). Similarly the germination, seedling vigour and field emergence \% decreases with increasing the storage periods. In costal region of Andhra Pradesh percent germinability of Bengal gram was found to decrease from $81 \%$ to $65 \%$ within 4 months of storage (Vimla and Pushpamma, 1993). Charjan and Tarar (1994) and Gadewar et al. (2011) reported that the germination percentage, seedling vigour and field emergence percentage decreases with increasing storage periods in moth bean and pigeon pea infested by pulse beetles during storage.

Pulse beetle feeds on the cotyledonous portion of the Kabuli Chana seed leaving the seed coat intact and that is one reason that higher values for crude fibre and total ash have been obtained in infested seed, as seed coat is rich in crude fibre and minerals (Singh et al. 1968 and Shrivastava et al. 1989). Increase in protein content is attributed to insect metabolites like uric acid, which is nitrogenous in nature (Shrivastava et al. 1989). Increase in reducing sugars and decreasing in non-reducing sugars has been shown in stored Kabuli Chana seeds. Similar results have been reported by Khare (1972), Shrivastava et al. (1989) Gadewar et al. (2011) Charjan and Tarar (1994). The following fungi were found to be associated with stored seeds of Kabuli Chana. The present pulse beetles damaged seeds yielding a particular fungus viz., Alternaria sp., Aspergillus sp., Curvualaria sp., Fusarium sp., Penicillium sp. and Rhizopus sp. irrespective of storage periods. In the present study, the incidence percentage of storage fungi increases with increasing seed damages by pulse beetles and storage periods. 
The results are in conformity with the results of Charjan et al. (2006) and Gadewar et al. (2011)

Thus from the present study, it can be concluded that infestation of pulse beetle in Kabuli Chana increases the moisture content which is favorable for multiplication of fungal flora and decreases the 100-seed weight, germinability, seedling vigour and field emergence percentage of seeds during storage. It also observed that the decrease of the crude fat, total carbohydrates and total sugars and increase of total ash, crude fibre and crude protein in infested Kabuli Chana. Increase in protein content is attributed to insect metabolites like uric acid, which is nitrogenous in nature. The percentage of storage fungi increases with increasing pulse beetles damage and storage period. Among the identified fungi species, many were well known toxin producers. The pulse beetle infested Kabuli Chana seeds should be avoided for sowing or consumption purposes.

\section{CONCLUSIONS}

It is difficult to estimate the effects of air pollutants because the organisms are exposed to a wide range of uncontrolled variables (parasites, weather conditions, complex mixture of pollutants). On the morphological, anatomical and physiological point of view, the plants from polluted sites present important changes especially regarding their colors, shapes, leaf length, width, stomatal and trichome frequency and chlorophyll content. However, despite of these changes, plants were survived well at the polluted environment of Koradi and Khaperkheda. These results showed the importance of morphological data for precocious diagnosis injury and to determine the sensitivity of different plant species to the action of air pollutants. After this study, we can consider that there is still a serious lack of knowledge of the impact of air quality on vegetation in the industrial urban areas. Overall, the study reveals that all the plant species growing in the polluted environment of the thermal power plant are badly affected by emission. There is a need to set limits on how much of a pollutant is allowed in the air. The exchange of experience and information from the developed countries on this aspect of pollution impact on plants might be useful. Our goal must be to have clean air for flora and fauna. We should take necessary steps to get rid of the ever increasing pollution.

\section{ACKNOWLEDGEMENTS}

I express my deep gratitude to Dr.N.M.Dongarwar, Assistant Professor, Department of Botany, Rashtrasant Tukdoji Maharaj Nagpur University, for initially suggesting the problem and guidance throughout the progress of work. The critical observation, encouragement and suggestion given from time to time cannot be expressed in word. I am thankful to Dr. Alka Chaturvedi Prof. \& Head, P.G Department of Botany, R.T.M. Nagpur University, for providing me necessary facilities for completion of project.

\section{REFERENCES:-}

Abdul Baki, A. A. and Anderson, A.A. 1973. Vigour determination in soybean seed by multiple criteria. Crop Science. 13: 630-633.

Charjan, S.K.U. 1995. Efficacy of Acorus calamus L. rhizome powder against the pulse beetle, Callosobruchus chinensis L. infested stored pigeon pea (Cajanus cajan). In : Herbal, medicine, biodiversity and conservation strategies (Ed. Rajak and M.K.Rai) International Book Distributor, Deharadun: 242-246.

Charjan, S.K.U. and Tarar, J. L. 11994. Biochemical changes in jowar grains due to infestation of rice weeil and khapra beetel during storage proceeding National Academy of Science. 64 (B) IV: 381-384.

Charjan, S.K.U., Wankhede, S.R. and Jayade, K.G. 2006. Viability, vigour and mycoflora changes in pulse beetle (Callosobruchus sp.) damaged seeds of cowpea produced in dryland condition. In: Economics of sustainability of dryland agriculture, Nagpur: 5-6.

Cristensen, C.M. and Kaufmann, H.H. 1969. Grain Storage- the role of fungi in quality loss. 153 pp. Univ. of Minnesola Press, Minneapolis.

Gadewar, R., A. Lambar, S.Charjan, P. Charde, K. Cherian and P. Lambat. 2011 Post harvest 
losses in qualities of pigeon pea due to pulse beetle infesttion. In: Proc. International conference in Agricultural engineering. Chonburi, Thailand Page No. C/45-51.

AACC. 1962. Approved methods of American Association of Cereal Chemist, $8^{\text {th }}$ rev. ed. St. Paul (Minnesota)

ISTA. 1976. International rules for seed testing. Seed Sci. and Technol. 4: 108.

ISTA. 1985. International rules for seed testing . Seed Sci. and Technol. 13: 299-513.

Joslyn, M.A. 1970. Methods of food analysis: Physical, chemical and instrumental methods of analysis. Academic Press, New York: 845.

Khare, B.P. 1972. Insect pest of stored grain and their control in Uttar Pradesh. Research Bulletin. No. 5 G.B.U.A.T., Panthagar: 132-139.
Panse, V.G. and Sukhatme, P.V. 1967. Statistical methods for agril Workers, I.C.A.R. Publication, New Delhi.

Shrivastava, S., Gupta, K.C. and Agrawal, A. 1989. Japanese mint oil as fumigant and its effect on insect infestation, nutritive value and germinability of pigeon pea seed during storage. Seed Res. 17 (1) : 96-98.

Singh, S., Singh, H.D. and Sikka, K.C. 1968. Distribution of nutrients in anatomical parts of common Indian pulses. Cereal Chem. 45: 1318.

Vimla, V. and Pushpamma, P. 1983. Storage quality of pulses stored in three agroclimatic regions of Andhra Pradesh II. Viability Changes. Bull. Grain 21(3): 217-22.

Table 1; Effect of pulse beetle infestation on physical, physiological, biochemical and mycological qualities of Kabuli Chana during storage.

\begin{tabular}{|c|c|c|c|c|}
\hline & Seed Quality parameters & Initial & After 3 months & After 6 months \\
\hline A & $\begin{array}{l}\text { Physical seed quality } \\
\text { 1. Seed moisture (\% wb) } \\
\text { 2. Seed damage }(\%) \\
\text { 3. } 100 \text {-seed weight (gm) }\end{array}$ & $\begin{array}{c}10.2 \\
0.00 \\
10.01\end{array}$ & $\begin{array}{c}11.1 \\
26.7 \\
8.9\end{array}$ & $\begin{array}{c}15.7 \\
55.6 \\
7.9\end{array}$ \\
\hline B & $\begin{array}{l}\text { Physiological seed quality } \\
\text { 1. Germination (\%) } \\
\text { 2. Seedling Vigour Index } \\
\text { (SVI) } \\
\text { 3. Field emergence (\%) }\end{array}$ & $\begin{array}{c}90 \\
4156 \\
81\end{array}$ & $\begin{array}{c}80 \\
3002 \\
71\end{array}$ & $\begin{array}{c}59 \\
2143 \\
50\end{array}$ \\
\hline C & $\begin{array}{l}\text { Biochemical seed quality } \\
\text { 1. Total ash (\%) } \\
\text { 2. Crude fibre (\%) } \\
\text { 3. Crude Protein }(\%) \\
\text { 4. Crude fat } \\
\text { 5. Total carbohydrate } \\
\text { 6. Total sugar (\%) } \\
\text { 7. Reducing sugar }(\%)\end{array}$ & $\begin{array}{c}4.94 \\
8.3 \\
23.88 \\
3.4 \\
72.4 \\
9.0 \\
13.4\end{array}$ & $\begin{array}{c}5.53 \\
9.2 \\
25.88 \\
3.0 \\
68.5 \\
8.1 \\
9.9\end{array}$ & $\begin{array}{c}6.32 \\
9.9 \\
30.1 \\
2.1 \\
61.9 \\
6.4 \\
2.3\end{array}$ \\
\hline
\end{tabular}


I J R B A T, Issue (VII), Vol. III, Sept 2019: 29-33

\begin{tabular}{|l|l|c|c|c|}
\hline & 8. Non-reducing sugar & 8.4 & 7.1 & 6.0 \\
\hline \multirow{5}{*}{ D } & Mycological observation & & & \\
& 1. Alternaria sp. (\%) & 8.50 & 5.75 & 3.75 \\
& 2. Aspergillus sp. (\%) & 2.50 & 8.75 & 20.25 \\
& 3. Curvualaria sp. (\%) & 1.50 & 4.25 & 18.25 \\
& 4. Fusarium sp. (\%) & 0.50 & 5.25 & 10.75 \\
5. Penicillium sp. (\%) & 0.00 & 3.75 & 10.25 \\
& 6. Rhizopus sp. (\%) & 0.00 & 3.25 & 9.75 \\
& 7. Total incidence (\%) & 13.00 & 31.00 & 73.00 \\
\hline
\end{tabular}

